\title{
In vitro Efficacy of Native Trichoderma Isolates against Pythium spp. and Rhizoctonia solani (Kuhn.) causing Damping-off Disease in Tomato (Solanum lycopersicum Miller)
}

\author{
Markidahun Biam*, Dipali Majumder and Heipormi Papang
}

\begin{abstract}
Department of Plant Pathology, College of Post Graduate Studies, Central Agricultural University, Umiam-793103, Meghalaya, India
\end{abstract}

*Corresponding author

\section{Keywords}

Meghalaya, Damping off, Trichoderma spp., Pythium spp., Rhizoctonia solani, Tomato, per cent inhibition, PGPR and biocontrol potential

\section{Article Info}

Accepted:

04 January 2019 Available Online: 10 February 2019
The present study was conducted to evaluate the in vitro efficacy of native Trichoderma spp. against Pythium spp. and Rhizoctonia solani (Kuhn.) causing damping-off disease in Tomato. One hundred eighty soil samples were collected from 11 districts of Meghalaya and ninety seven Trichoderma isolates were obtained. Rapid screening against damping off pathogens (Pythium spp. and R. solani) of tomato revealed that 20 isolates showed maximum antagonism and subsequently 20 best isolates were selected for further analysis. Isolate TR 55 isolated from tomato rhizosphere was found to be the most effective isolate against both Pythium spp. and $R$. solani Kuhn, showing an inhibition percentage of $89.26 \%$ and $87.41 \%$ respectively, followed by other isolates like TR 66, TR 122 and TR 136. Screening for the PGPR and biocontrol potential of the twenty potential isolates revealed that all isolates were found positive for IAA production, ACC deaminase production and phosphorous solubilization, whereas 17 positive for chitinase production, 16 isolates were found positive for siderophore and ammonia production and 13 isolates were positive for HCN production.

\section{Introduction}

Tomato (Solanum lycopersicum Miller) is one of the most important temperate vegetable crops throughout the world and is also widely cultivated in Meghalaya, India. Tomato production has a major role in global horticulture, ranking second in importance next to potato in many countries (Sharma et al., 2014). The main advantage of tomato farming is that it can be grown either in the field or under greenhouse conditions. Tomatoes are a good source of potassium, vitamin $\mathrm{C}$, vitamin $\mathrm{A}$ and excellent antioxidant lycopene. They help in fighting cancer, reducing heart disease and are also good for eye health and digestion (Nahar and Ullah, 2012).

China is leading producer among Asian countries, followed by India. In India, tomato is cultivated as one of the leading vegetable 
crops, covering an area of 8.65 lakh hectares with a total production of 168.26 lakh tonnes having productivity of 19.60 tonnes ha-1 (Anon, 2014). Bihar, Karnataka, Odisha, Maharashtra, Himachal Pradesh, West Bengal, Tamil Nadu, Uttar Pradesh and Gujarat are major tomato growing states (Ghinaiya and Pandya, 2017) and among them Karnataka is the largest producer state in India. These States account for $91 \%$ of the total production of the country. Meghalaya accounts for 36.60 million tonnes of tomato production, which is $0.16 \%$ of country's total tomato production (Anon, 2018).

Although tomato is commercially grown across the globe, there is no place where the plant is free from diseases. One of the major causes of seedling loss is damping-off, a disease that is mainly caused by Pythium spp. and Rhizoctonia solani Kuhn, which are responsible for seed decay as well as preemergence and post-emergence damping-off of tomato seedlings. Most of these fungi can also cause cuttings to rot (Thakur and Tripathi, 2015).

Management of damping off by fungicides is not the most desirable means of disease management, for several important reasons. Fungicides are heavily regulated and additionally, they are expensive, cause environmental pollution, and may induce pathogen resistance (Lamichhane et al., 2017). Since cultural practices alone are not always sufficient to effectively manage the disease, alternative strategies are needed. Therefore, management of plant pathogens using microbial bio inoculants has been considered as a potential management strategy for integrated disease management. Many researchers have demonstrated the potential of Trichoderma spp. in management of damping-off diseases of crop plants caused by Pythium spp. (Lamichanne et al., 2017; Majeed et al., 2018; Al-shemamary et al.,
2018) and Rhizoctonia solani (Asad et al., 2014; Abbas et al., 2017; Mangariello et al., 2018). Trichoderma spp. are widely distributed all over the world and found in all natural habitats especially in those containing forest humus layer (Wardle et al., 1993) as well as in agricultural orchard soils (Roiger et al., 1991) and soil consisting of organic matter (Papavizas, 1985). It is known to be one of the best candidates of BCA against wide range of plant pathogens.

Therefore, in the present investigation major emphasis was to study the bio-efficacy of native Trichoderma isolates against damping off caused by Pythium spp. and Rhizoctonia solani Kuhn.

\section{Materials and Methods}

\section{Isolation, identification and maintenance of pathogen}

Pythium spp. and $R$. solani Kuhn. were isolated from naturally infected tomato, showing damping off symptoms (soft rot and wire stem symptom for Pythium spp. and $R$. solani respectively) and pathogenicity test was carried out in SCP, CPGS, CAU, Umiam, Meghalaya. Diseased samples collected from farmers' fields were brought to laboratory and isolations were done. With repeated isolations, Pythium spp. and $R$. solani Kuhn were consistently found with the infected seedlings of tomato. Pythium spp. cultures isolated from the infected tomato seedlings were identified based on the types of fungal mycelium and filamentous sporangia with terminal, smooth and spherical oospores as compared with the old cultures available in the Laboratory. Also $R$. solani Kuhn was identified based on the hyphae that tend to branch at right angles and a septum near each and a slight constriction at the branch are diagnostic. The fungus was purified by hyphal tip cut method. The purified culture was 
maintained on PDA slants at $4^{\circ} \mathrm{C}$ in refrigerator.

\section{Collection and isolation of Trichoderma from different locations of Meghalaya}

Soil samples from root rhizosphere, coal mines, jhum fallows, manure compost and submerged areas were collected from 11 districts of Meghalaya. Isolation of Trichoderma was done by dilution plate method using PDA (Dhingra and Sinclair, 1995). One gram of soil was suspended in 250 $\mathrm{ml}$ Erlenmeyer flasks with $100 \mathrm{ml}$ sterilized distilled water. Samples were shaked for 20 30 minutes on a rotary shaker at $250 \mathrm{rpm}$ and dilutions of $10^{-1}, 10^{-2}, 10^{-3}, 10^{-4}$ and $10^{-5}$ were made for each soil samples. An aliquot of 0.1 $\mathrm{ml}$ of substrate suspension was dispensed on PDA. The Petriplates $(90 \mathrm{~mm}$ in dia) were incubated at $28 \pm 1^{\circ} \mathrm{C}$ for 24 hours. Morphologically distinct colony was isolated, purified and grown in pure culture on PDA. The obtained fungal isolates were grown on PDA slants and kept at $4^{\circ} \mathrm{C}$ until being used. Isolated Trichoderma was grown on Malt Extract Agar (MEA) medium and identified based on characters viz. conidiophores, phialides and conidia (Rifai, 1969; Bisset, 1992). Microscopic examination was carried out by mounting the culture in lactophenol cotton blue.

\section{Rapid screening of Trichoderma isolates}

Isolates tentatively identified as Trichoderma were exposed to rapid screening of Trichoderma isolates against Pythium spp. and $R$. solani Kuhn. by dual culture technique on PDA medium on the basis of their relative growth rate measured as a function of incubation period. Mycelial discs of $5 \mathrm{~mm}$ diameter was picked up from the margin of young 3-4 days old culture of Trichoderma and the respective pathogens were inoculated at the peripheral region of the Petriplates (90mm in dia) at equal distance from the centre and incubated for 5-6 days at $28 \pm 1^{\circ} \mathrm{C}$. The relative growth rate of test antagonist and the pathogen were observed and recorded. The most efficient Trichoderma isolate was sorted out as potent isolate against the respective pathogen. These isolates were multiplied and maintained as mentioned earlier for long term preservation and preserved at $4^{\circ} \mathrm{C}$ in PDA slants for subsequent use.

The Trichoderma isolates were rated on the basis of their ability to suppress the mycelia growth of pathogen following the methods of modified Bell's scale (Bell et al., 1982).

$\mathrm{S}_{1}$ : The antagonist completely overgrew the pathogen (100\% over growth)

$\mathrm{S}_{2}$ : The antagonist overgrew at least $2 / 3^{\text {rd }}$ growth of the pathogen (75\% overgrowth)

$S_{3}$ : The antagonized colonized half of the growth of pathogen (50\% overgrowth)

$\mathrm{S}_{4}$ : The pathogen and antagonist (locked at the point of contact)

$\mathrm{S}_{5}$ : The pathogen overgrew the antagonist

The experiment was conducted with three replicates per treatments.

\section{Efficacy of Trichoderma isolates against Pythium spp. and $R$. solani Kuhn}

The potential Trichoderma isolates were further evaluated for their antagonistic potential in vitro against Pythium spp. and $R$. solani Kuhn. through dual culture technique (Ramanathan et al., 2013).

\section{Dual culture technique}

For mycelial growth inhibition of test plant pathogens by the Trichoderma spp., both pathogens (Pythium spp, R. solani Kuhn.) and antagonists were inoculated at peripheral region opposite to each other in sterilized Petriplates $(90 \mathrm{~mm}$ dia) containing $20 \mathrm{ml}$ 
sterilized PDA medium and incubated at $28 \pm 1^{\circ} \mathrm{C}$. Plates inoculated with the pathogens only served as the control. Observation for the dual inoculation of the Trichoderma spp. and the pathogen was taken till the growth of the pathogen fully covered the plate. The experiment was replicated three times. The suppression effect of all Trichoderma spp. isolates were evaluated in terms of Percentage Inhibition in Radial Growth (PIRG) of Pythium spp. and $R$. solani based on the following formula (Gaigole et al., 2011).

$$
P I R G=R 1-R 2 \times \underline{100 \%}
$$

$\mathrm{R} 1$

$\mathrm{R} 1=$ Radial growth of Pythium spp. and $R$. solani in the absence of the antagonist in the respective plate (control)

R2 = Radial growth of Pythium spp. and $R$. solani in the presence of the Trichoderma isolates (treatment)

\section{Screening of isolated Trichoderma for In vitro plant growth promoting and biocontrol potential}

\section{Chitinolytic enzyme assay}

The strains of Trichoderma isolates were determined for chitinolytic activity on chitin detection medium (Thakar and Saraf, 2015).

\section{Preparation of colloidal chitin}

$5.0 \mathrm{~g}$ of chitin was added to $60 \mathrm{ml}$ of conc. $\mathrm{HCl}$ (acid hydrolysis) by constant stirring using a magnetic stirrer at $4^{\circ} \mathrm{C}$ and kept in refrigerator overnight. The resulting slurry was then added to $200 \mathrm{ml}$ of ice-cold $95 \%$ ethanol and kept at $26{ }^{\circ} \mathrm{C}$ overnight (ethanol neutralization). Then it was centrifuged at $3,000 \mathrm{rpm}$ for $20 \mathrm{~min}$ at $4^{\circ} \mathrm{C}$. The pellet was repeatedly washed with sterile distilled water by centrifugation at 3,000 rpm for $5 \mathrm{~min}$ at 4
${ }^{\circ} \mathrm{C}$ until the smell of alcohol vanished. The final colloidal chitin was stored at $4{ }^{\circ} \mathrm{C}$ until further use.

\section{Chitinase detection medium}

The final chitinase detection medium per litre comprised of $4.5 \mathrm{~g}$ colloidal chitin, $0.3 \mathrm{~g}$ magnesium sulphate, $3.0 \mathrm{~g}$ ammonium sulphate, $2.0 \mathrm{~g}$ potassium dihydrogen phosphate, $1.0 \mathrm{~g}$ citric acid monohydrate, $15 \mathrm{~g}$ agar, $0.15 \mathrm{~g}$ bromocresol purple and 200ul of tween-80. The $\mathrm{pH}$ of the media was maintained at 4.7 and autoclaved at $121{ }^{\circ} \mathrm{C}$ for $15 \mathrm{~min}$. The fresh culture plugs of Trichoderma isolates to be tested for chitinase activity were inoculated into the sterile plates containing chitinase detection medium and incubated at $28 \pm 2{ }^{\circ} \mathrm{C}$ for $2-3$ days and observed for the coloured zone formation. Formation of purple coloured zone was observed and recorded.

\section{Siderophores production test}

The ability of Trichoderma spp. to produce iron-binding compounds of siderophore-type was detected in solid medium by universal Chrome Azurol S (C.A.S) assay (Srivastava et al., 2013)

\section{Preparation of the C.A.S. (Chrome Azurol S) Blue Agar}

One litre of C.A.S blue agar was prepared using $60.5 \mathrm{mg}$ C.A.S dissolved in $50 \mathrm{ml}$ distilled deionized water and mixed with 10 $\mathrm{ml}$ iron (III) solution $\left(1 \mathrm{mM} \mathrm{FeCl}{ }_{3} \cdot 6 \mathrm{H}_{2} \mathrm{O}, 10\right.$ $\mathrm{mM} \mathrm{HCI}$ ). Under stirring, this solution was slowly added to $72.9 \mathrm{mg}$ Hexadecyl tri methyl-ammonium bromide (HDTMA) dissolved in $40 \mathrm{ml}$ water. The resultant dark blue liquid was autoclaved for $20 \mathrm{~min}$. Also autoclaved a mixture of $750 \mathrm{ml}$ water, $15 \mathrm{~g}$ agar, $30.24 \mathrm{~g}$ Pipes and $12 \mathrm{~g}$ of a solution of $50 \%(\mathrm{w} / \mathrm{w}) \mathrm{NaOH}$ to raise the $\mathrm{pH}$ to the $\mathrm{pKa}$ 
of Pipes (6.8). The dye solution was finally poured along the glass wall and agitated with enough care to avoid foaming. Petri dishes (9cm in diameter) were prepared with $30 \mathrm{ml}$ of PDA medium for culturing Trichoderma spp. After solidification, the medium was cut into halves, one of which was replaced by C.A.S. blue agar $(15 \mathrm{ml})$. The halves containing culture medium were inoculated with $5 \mathrm{~mm}$ discs of seven days old culture of Trichoderma strains. The inoculum was placed as far as possible, from the borderline between the two media. The plates were incubated at $28 \pm 2^{\circ} \mathrm{C}$ for 7 days in the dark. Colour-changed from blue to purple or dark purplish- red (magenta) in the C.A.S.-blue agar, starting from the borderline between the two media was considered positive for siderophore production. The experiment was carried out in triplicates. The control plates of C.A.S.-agar uninoculated were incubated under the same conditions as described above. The experiment was conducted with three replicates per treatments.

\section{HCN production}

Production of $\mathrm{HCN}$ was detected by inoculated different isolates of Trichoderma spp. separately onto the PDA medium amended with $4.4 \mathrm{~g} / \mathrm{ml}$ glycine and lid of plate was covered with the soaked Whatsman no. 1 filter paper in $0.5 \%$ picric acid and in $2 \%$ sodium carbonate, then incubated for 5-7 days at $28 \pm 1{ }^{\circ} \mathrm{C}$. Change in colour of filter paper from deep yellow to orange and finally to orange brown to dark brown indicated the positive reaction. The experiment was conducted with three replicates per treatments (Dixit et al., 2015)

\section{Indole-3-acetic acid (IAA) estimation test}

Quantitative estimation of IAA was done through addition of tryptophan in the potato dextrose broth (PDB) for Trichoderma spp. and incubated at $25 \pm 1^{\circ} \mathrm{C}$ for seven days and filtered with Whatman No. 2 filter paper, then $1 \mathrm{ml}$ filtrate was mixed with $2 \mathrm{ml}$ Salkowski reagent $\left(2 \% \quad 0.5 \mathrm{M} \mathrm{FeCl}_{3}\right.$ in $35 \%$ perchloric acid) in a test tube (Gravel et al., 2007). The mixture was incubated at room temperature for 20 minutes. Pink colour producing samples was considered as positive reaction and absorbance was measured at $540 \mathrm{~nm}$ by spectrophotometer. A standard curve was prepared using IAA and the presence of IAA in the culture filtrate was quantified. The IAA produced was compared to the standard graph and expressed as $\mu \mathrm{g} / \mathrm{ml}$ (Dixit et al., 2015).

\section{Phosphate (P) solubilization}

Solubilization of $\mathrm{P}$ was tested quantitatively using $20 \mathrm{ml}$ Pikovskaya's broth medium (PKV) amended with $5 \mathrm{~g} / \mathrm{l}$ tricalcium phosphate $(17 \% \mathrm{P})$ then inoculated with a mycelial disc of seven days old culture of Trichoderma spp. and incubated at $28 \pm 1{ }^{\circ} \mathrm{C}$ on a shaker for 3-4 days. Uninoculaed PKV broth served as control in each case. Each experiment was done in triplicate set. Mycelial growth was filtered through Whatman No. 42 filter paper and $50 \mu \mathrm{l}$ of resultrant filtrate was added with $500 \mu$ of ammonium molybdate solution and shaked well. An addition of $2 \mathrm{ml}$ distilled water, $13 \mu \mathrm{l}$ chlorostannous acid and $2.5 \mathrm{ml}$ distilled water was made. Blue colour intensity was recorded by spectrophotometer at $600 \mathrm{~nm}$. The available phosphorus in the culture filtrate was calculated from a standard curve prepared using various concentration of standard $\mathrm{K}_{2} \mathrm{HPO}_{4}$ solution and the results were expressed in $\mu \mathrm{g} / \mathrm{ml}$ (Rudresh et al., 2005).

\section{ACC deaminase production test}

The ACC deaminase production of the Trichoderma isolates was screened using the methods described by Jasim et al., (2014). For 
this, the isolates were inoculated on to Difco (DF) salts minimal medium (potassium dihydrogen phosphate $4 \mathrm{~g} / \mathrm{L}$, disodium hydrogen phosphate $6 \mathrm{~g} / \mathrm{L}$, magnesium sulfate heptahydrate $0.2 \mathrm{~g} / \mathrm{L}$, ferrous sulfate heptahydrate $0.1 \mathrm{~g} / \mathrm{L}$, boric acid $10 \mu \mathrm{g} / \mathrm{L}$, manganese(II) sulfate $10 \mu \mathrm{g} / \mathrm{L}$, zinc sulphate $70 \mu \mathrm{g} / \mathrm{L}$, copper (II) sulfate $50 \mu \mathrm{g} / \mathrm{L}$, molybdenum (VI) oxide $10 \mu \mathrm{g} / \mathrm{L}$, glucose 2 $\mathrm{g} / \mathrm{L}$, gluconic acid $2 \mathrm{~g} / \mathrm{L}$, citric acid $2 \mathrm{~g} / \mathrm{L}$, agar $12 \mathrm{~g} / \mathrm{L}$ ) amended with $0.2 \%$ ammonium sulphate $(\mathrm{w} / \mathrm{v})$. The fungal growth in this media after 4-7 days of incubation was considered as positive result. The experiment was conducted with three replicates per treatments.

\section{Ammonia production}

Trichoderma isolates was tested for the production of ammonia in peptone water. Freshly grown cultures were inoculated in 10 $\mathrm{ml}$ peptone water separately and incubated for $48-72 \mathrm{~h}$ at $36 \pm 2{ }^{\circ} \mathrm{C}$. Nessler's reagent $(0.5$ $\mathrm{ml}$ ) was added in each tube. Development of yellow to brown colour indicated for positive test (Thakkar and Saraf, 2015). The experiment was conducted with three replicates per treatments.

\section{Results and Discussion}

Soil samples collected from different locations of Meghalaya were tested. The isolates showing the lime green to greenish colour sporulation with highly fluffy growth and sparse to compact colony after 7-10 days of incubation were selected. The selected isolates were grown on Malt Extract Agar (MEA) to observe conidiophores, phialides and conidia. Based on taxonomic keys provided by Rifai (1969) Bisset (1992), it is evident that altogether ninety seven (97) Trichoderma isolates were isolated from 180 soil samples collected.
Rapid screening of Trichoderma isolates was done against Pythium spp. and $R$. solani Kuhn. by dual culture in potato dextrose agar and the results showed that 77 isolates attained $\mathrm{S}_{4}$ stage (the pathogen and antagonist locked at the point of contact), 8 isolates showed $\mathrm{S}_{3}$ stage (the antagonized colonized half of the growth of pathogen i.e. $50 \%$ overgrowth) and remaining 12 isolates showed $\mathrm{S}_{2}$ stage (the antagonist overgrew at least $2 / 3^{\text {rd }}$ growth of the pathogen i.e. $75 \%$ growth) from 4-7 days after inoculation on the basis of modified Bell's scale (Plate 1).

The study of antagonistic potential of 20 screened isolates of Trichoderma spp. against damping-off pathogens which showed $\mathrm{S}_{2}$ and $\mathrm{S}_{3}$ stage on the basis of modified Bell's scale revealed that all 20 isolates showed an inhibition percentage of more than $65 \%$. Among which 4 Trichoderma isolates viz. TR 55, TR 66, TR 122 and TR 136 were most effective in inhibiting Pythium spp. with percent inhibition of $89.26 \%, 88.15 \%$, $88.89 \%$ and $87.78 \%$ respectively, whereas only 2 isolates viz. TR 55 and TR 122 were found effective against $R$. solani with percent inhibition of $87.41 \%$ and $86.48 \%$ respectively (Table 1).

The result (Table 2, Plate 2) showed that out of 20 screened isolates, only 16 isolates were positive for siderophore production as indicated by colour-changed from blue to purple or dark purplish- red (magenta) in the C.A.S.-blue agar. Also 16 isolates were positive for ammonia production indicated by development of yellow to brown colour in Nessler's reagent whereas 17 isolates were positive for chitinase and 13 isolates were positive for $\mathrm{HCN}$ production as evidenced by the change in the colour of filter paper. However all 20 screened isolates grew on Difco (DF) salts minimal medium showing their ability to produce ACC deaminase. 
Table.1 In vitro efficacy of Trichoderma isolates against Pythium spp and $R$. solani

\begin{tabular}{|c|c|c|c|c|c|}
\hline \multirow{2}{*}{$\begin{array}{l}\text { Sl. } \\
\text { No. }\end{array}$} & \multirow{2}{*}{$\begin{array}{c}\text { Trichoderma } \\
\text { isolates }\end{array}$} & \multicolumn{2}{|c|}{ Growth $(\mathrm{cm})$} & \multicolumn{2}{|c|}{ Per cent inhibition over control } \\
\hline & & Pythium spp & R. solani & Pythium spp & R. solani \\
\hline 1. & TR 12 & $\begin{array}{c}2.00 \pm 0.06^{\mathrm{d}} \\
(1.41)\end{array}$ & $\begin{array}{c}1.90 \pm 0.06^{\mathrm{ij}} \\
(1.37)\end{array}$ & $\begin{array}{c}77.78 \pm 0.64^{\mathrm{e}} \\
(61.88)\end{array}$ & $\begin{array}{c}78.89 \pm 0.64^{\mathrm{de}} \\
(62.65)\end{array}$ \\
\hline 2. & TR 24 & $\begin{array}{c}2.43 \pm 0.07^{c} \\
\quad(1.56)\end{array}$ & $\begin{array}{c}2.07 \pm 0.09^{\mathrm{gh}} \\
(1.43)\end{array}$ & $\begin{array}{c}72.96 \pm 0.74^{1} \\
(58.67)\end{array}$ & $\begin{array}{c}77.04 \pm 0.98^{\mathrm{tg}} \\
(61.37)\end{array}$ \\
\hline 3. & TR 36 & $\begin{array}{c}2.80 \pm 0.06^{b} \\
(1.67)\end{array}$ & $\begin{array}{c}2.33 \pm 0.03^{\text {cde }} \\
(1.52)\end{array}$ & $\begin{array}{c}68.89 \pm 0.64^{j} \\
(56.10)\end{array}$ & $\begin{array}{c}74.07 \pm 0.37^{\mathrm{jk}} \\
(59.39)\end{array}$ \\
\hline 4. & TR 40 & $\begin{array}{c}2.23 \pm 0.07^{c} \\
(1.49)\end{array}$ & $\begin{array}{c}2.07 \pm 0.03^{\text {gh }} \\
(1.43)\end{array}$ & $\begin{array}{c}75.19 \pm 0.74^{\mathrm{t}} \\
(60.12)\end{array}$ & $\begin{array}{c}77.04 \pm 0.37^{\mathrm{tg}} \\
(61.37)\end{array}$ \\
\hline 5. & TR 55 & $\begin{array}{l}0.97 \pm 0.03^{\mathrm{h}} \\
\quad(0.98)\end{array}$ & $\begin{array}{c}1.13 \pm 0.03^{\circ} \\
(1.06)\end{array}$ & $\begin{array}{l}89.26 \pm 0.37^{\mathrm{a}} \\
(70.87)\end{array}$ & $\begin{array}{c}87.41 \pm 0.37^{\mathrm{a}} \\
(69.22)\end{array}$ \\
\hline 6. & TR 64 & $\begin{array}{c}1.97 \pm 0.07^{\mathrm{d}} \\
(1.40)\end{array}$ & $\begin{array}{l}1.97 \pm 0.07^{\mathrm{hi}} \\
(1.40)\end{array}$ & $\begin{array}{c}78.15 \pm 0.74^{\mathrm{e}} \\
(62.13)\end{array}$ & $\begin{array}{c}78.15 \pm 0.74^{\mathrm{ef}} \\
(62.13)\end{array}$ \\
\hline 7. & TR 66 & $\begin{array}{c}1.07 \pm 0.03^{\mathrm{h}} \\
(1.03)\end{array}$ & $\begin{array}{c}1.43 \pm 0.03^{1} \\
(1.19)\end{array}$ & $\begin{array}{c}88.15 \pm 0.37^{\mathrm{a}} \\
(69.86)\end{array}$ & $\begin{array}{c}84.07 \pm 0.37^{b} \\
(66.47)\end{array}$ \\
\hline 8. & TR 74 & $\begin{array}{c}2.00 \pm 0.00^{\mathrm{d}} \\
(1.41)\end{array}$ & $\begin{array}{c}1.73 \pm 0.03^{\mathrm{k}} \\
(1.31)\end{array}$ & $\begin{array}{c}77.78 \pm 0.00^{\mathrm{e}} \\
(61.87)\end{array}$ & $\begin{array}{c}80.74 \pm 0.37^{\mathrm{c}} \\
(63.97)\end{array}$ \\
\hline 9. & TR 78 & $\begin{array}{c}1.83 \pm 0.09^{\mathrm{de}} \\
(1.35)\end{array}$ & $\begin{array}{l}2.40 \pm 0.06^{\mathrm{c}} \\
\quad(1.54)\end{array}$ & $\begin{array}{c}79.63 \pm 0.98^{\mathrm{de}} \\
(63.18)\end{array}$ & $\begin{array}{c}73.33 \pm 0.64^{1} \\
(58.91)\end{array}$ \\
\hline 10. & TR 82 & $\begin{array}{c}1.93 \pm 0.09^{d} \\
(1.39)\end{array}$ & $\begin{array}{c}2.23 \pm 0.07^{\mathrm{det}} \\
(1.49)\end{array}$ & $\begin{array}{c}78.52 \pm 0.98^{\mathrm{e}} \\
(62.40)\end{array}$ & $\begin{array}{c}75.19 \pm 0.74^{\text {hij }} \\
(60.12)\end{array}$ \\
\hline 11. & TR 87 & $\begin{array}{c}2.37 \pm 0.03^{c} \\
(1.54)\end{array}$ & $\begin{array}{c}2.18 \pm 0.04^{\mathrm{etg}} \\
(1.47)\end{array}$ & $\begin{array}{c}73.70 \pm 0.37^{\mathrm{h}} \\
(59.14)\end{array}$ & $\begin{array}{c}75.74 \pm 0.49^{\text {ghi }} \\
(60.49)\end{array}$ \\
\hline 12. & TR 88 & $\begin{array}{c}1.57 \pm 0.03^{\mathrm{tg}} \\
(1.25)\end{array}$ & $\begin{array}{c}1.53 \pm 0.03^{1} \\
(1.23)\end{array}$ & $\begin{array}{c}82.59 \pm 0.37^{\mathrm{bc}} \\
(65.34)\end{array}$ & $\begin{array}{c}82.96 \pm 0.37^{b} \\
(65.62)\end{array}$ \\
\hline 13. & TR 106 & $\begin{array}{c}1.70 \pm 0.12^{\mathrm{ef}} \\
(1.30)\end{array}$ & $\begin{array}{c}2.30 \pm 0.00^{\mathrm{m}} \\
(1.51)\end{array}$ & $\begin{array}{c}81.11 \pm 1.28^{\mathrm{cd}} \\
(64.26)\end{array}$ & $\begin{array}{c}74.44 \pm 0.00^{1 \mathrm{jk}} \\
(59.63)\end{array}$ \\
\hline 14. & TR 109 & $\begin{array}{c}2.33 \pm 0.03^{\mathrm{c}} \\
1.53)\end{array}$ & $\begin{array}{c}2.12 \pm 0.10^{\mathrm{tg}} \\
(1.45)\end{array}$ & $\begin{array}{c}74.07 \pm 0.37^{\mathrm{tg}} \\
(59.39)\end{array}$ & $\begin{array}{c}76.48 \pm 1.13^{\text {gh }} \\
(61.00)\end{array}$ \\
\hline 15. & TR 112 & $\begin{array}{c}1.63 \pm 0.09^{f} \\
(1.28)\end{array}$ & $\begin{array}{l}2.63 \pm 0.03^{b} \\
\quad(1.62)\end{array}$ & $\begin{array}{c}81.85 \pm 0.98^{\mathrm{bc}} \\
(64.79)\end{array}$ & $\begin{array}{c}70.74 \pm 0.37 \mathrm{~m} \\
\quad(57.25)\end{array}$ \\
\hline 16. & TR 116 & $\begin{array}{c}1.83 \pm 0.07^{\mathrm{de}} \\
(1.35)\end{array}$ & $\begin{array}{c}2.35 \pm 0.05^{\mathrm{cd}} \\
(1.53)\end{array}$ & $\begin{array}{c}79.63 \pm 0.74^{\mathrm{de}} \\
(63.17)\end{array}$ & $\begin{array}{c}73.89 \pm 0.56^{\mathrm{jk}} \\
(59.27)\end{array}$ \\
\hline 17. & TR 122 & $\begin{array}{c}1.00 \pm 0.00^{\mathrm{h}} \\
(1.00)\end{array}$ & $\begin{array}{c}1.22 \pm 0.02^{\mathrm{no}} \\
(1.10)\end{array}$ & $\begin{array}{c}88.89 \pm 0.00^{\mathrm{a}} \\
(70.53)\end{array}$ & $\begin{array}{c}86.48 \pm 0.19^{\mathrm{a}} \\
(68.43)\end{array}$ \\
\hline 18. & TR 136 & $\begin{array}{c}1.10 \pm 0.06^{\mathrm{h}} \\
(1.05)\end{array}$ & $\begin{array}{c}1.82 \pm 0.06^{\mathrm{jk}} \\
(1.34)\end{array}$ & $\begin{array}{c}87.78 \pm 0.64^{\mathrm{a}} \\
(69.55)\end{array}$ & $\begin{array}{c}79.81 \pm 0.67^{\text {cd }} \\
(63.30)\end{array}$ \\
\hline 19. & TR 143 & $\begin{array}{c}1.47 \pm 0.03^{\mathrm{g}} \\
(1.21)\end{array}$ & $\begin{array}{c}2.37 \pm 0.03^{\mathrm{cd}} \\
(1.53)\end{array}$ & $\begin{array}{c}83.70 \pm 0.37^{b} \\
(66.19)\end{array}$ & $\begin{array}{c}73.70 \pm 0.37^{\mathrm{jk}} \\
(59.14)\end{array}$ \\
\hline 20. & TR 171 & $\begin{array}{c}1.63 \pm 0.09^{\mathrm{t}} \\
(1.28)\end{array}$ & $\begin{array}{l}2.70 \pm 0.06^{\mathrm{b}} \\
(1.64)\end{array}$ & $\begin{array}{c}81.85 \pm 0.98^{b c} \\
(64.79)\end{array}$ & $\begin{array}{c}70.00 \pm 0.64^{\mathrm{mn}} \\
(56.79)\end{array}$ \\
\hline 21. & Control & $\begin{array}{c}9.00 \pm 0.00^{\mathrm{a}} \\
(3.00)\end{array}$ & $\begin{array}{c}9.00 \pm 0.00^{\mathrm{a}} \\
(3.00)\end{array}$ & $\begin{array}{c}0.00 \pm 0.00^{k} \\
(0.36)\end{array}$ & $\begin{array}{c}0.00 \pm 0.00^{\circ} \\
(0.36)\end{array}$ \\
\hline & SE(m) & 0.002 & 0.001 & 0.72 & 0.44 \\
\hline & $\mathrm{D}(\mathbf{p}=\mathbf{0 . 0 5})$ & 0.06 & 0.051 & 1.40 & 1.10 \\
\hline
\end{tabular}

*Mean of three replications

Note: Figures in parentheses are square root transformed values for growth and arc sine transformed values for per cent inhibition over control. 
Table.2 PGPR and biocontrol efficacy of Trichoderma spp.

\begin{tabular}{|c|c|c|c|c|c|c|c|c|}
\hline $\begin{array}{l}\text { Sl. } \\
\text { No. }\end{array}$ & $\begin{array}{l}\text { Trichoder } \\
\text { ma spp }\end{array}$ & $\begin{array}{l}\text { Chitinase } \\
\text { production }\end{array}$ & $\begin{array}{l}\text { Siderophore } \\
\text { Production }\end{array}$ & $\begin{array}{c}\text { HCN } \\
\text { Production }\end{array}$ & $\begin{array}{l}\text { Ammonia } \\
\text { production }\end{array}$ & $\begin{array}{c}\text { ACC } \\
\text { deaminase } \\
\text { activity }\end{array}$ & $\begin{array}{l}\text { IAA produce } \\
\text { (ug/ml) }\end{array}$ & $\begin{array}{l}\text { Phosphorous } \\
\text { production } \\
\text { (ug/ml) }\end{array}$ \\
\hline 1. & TR 12 & + & ++ & - & - & + & 1.47 & 0.68 \\
\hline 2. & TR 24 & +++ & ++ & - & + & + & 0.84 & 0.21 \\
\hline 3. & TR 36 & + & + & - & - & + & 2.97 & 0.53 \\
\hline 4. & TR 40 & ++ & +++ & - & ++ & + & 3.22 & 0.22 \\
\hline 5. & TR 55 & ++ & +++ & + & +++ & + & 4.96 & 0.72 \\
\hline 6. & TR 64 & +++ & ++ & + & +++ & + & 1.81 & 0.41 \\
\hline 7. & TR 66 & ++ & + & ++ & ++ & + & 2.14 & 0.75 \\
\hline 8. & TR 74 & + & - & + & + & + & 2.45 & 0.09 \\
\hline 9. & TR 78 & + & ++ & - & - & + & 2.51 & 0.23 \\
\hline 10. & TR 82 & - & ++ & - & + & + & 1.53 & 0.03 \\
\hline 11. & TR 87 & ++ & ++ & + & + & + & 1.44 & 0.32 \\
\hline 12. & TR 88 & + & + & ++ & + & + & 4.70 & 0.58 \\
\hline 13. & TR 106 & +++ & + & + & + & + & 0.48 & 0.98 \\
\hline 14. & TR 109 & + & - & + & + & + & 0.48 & 0.74 \\
\hline 15. & TR 112 & + & +++ & ++ & + & + & 1.94 & 0.39 \\
\hline 16. & TR 116 & - & - & - & ++ & + & 0.33 & 0.32 \\
\hline 17. & TR 122 & +++ & ++ & ++ & +++ & + & 0.72 & 0.25 \\
\hline 18. & TR 136 & + & ++ & ++ & +++ & + & 0.99 & 0.79 \\
\hline 19. & TR 143 & ++ & - & + & - & + & 0.58 & 0.59 \\
\hline 20. & TR 171 & - & ++ & + & + & + & 0.87 & 0.29 \\
\hline
\end{tabular}

*Mean of three replications

$(+)$ indicates light color, $(++)$ indicates dark color and $(+++)$ indicates very dark color

(-) indicates absence

Plate.1 Rapid Screening of Trichoderma spp. following modified Bell's scale

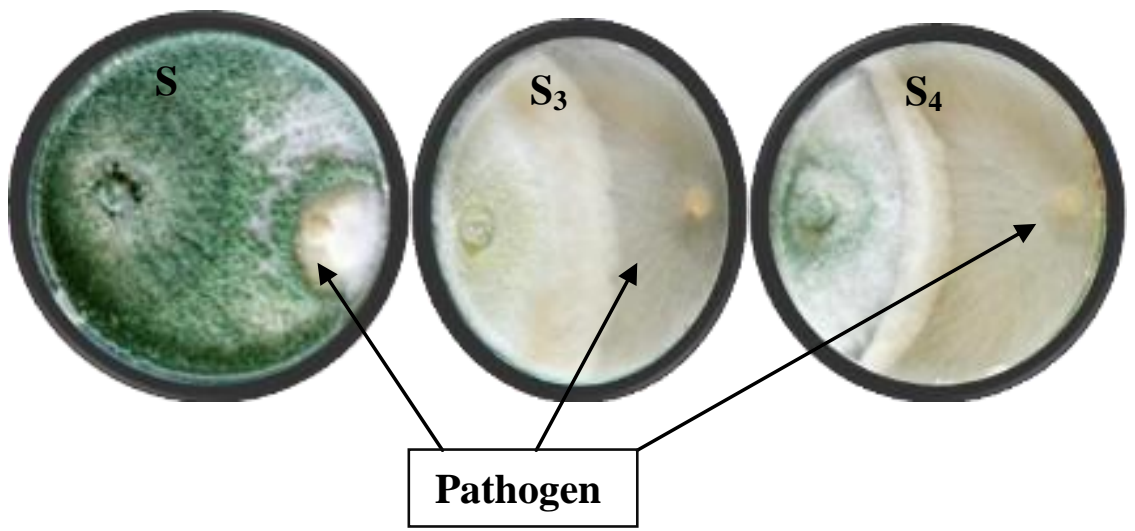


Plate.2 PGPR and biocontrol efficacy test of Trichoderma isolates

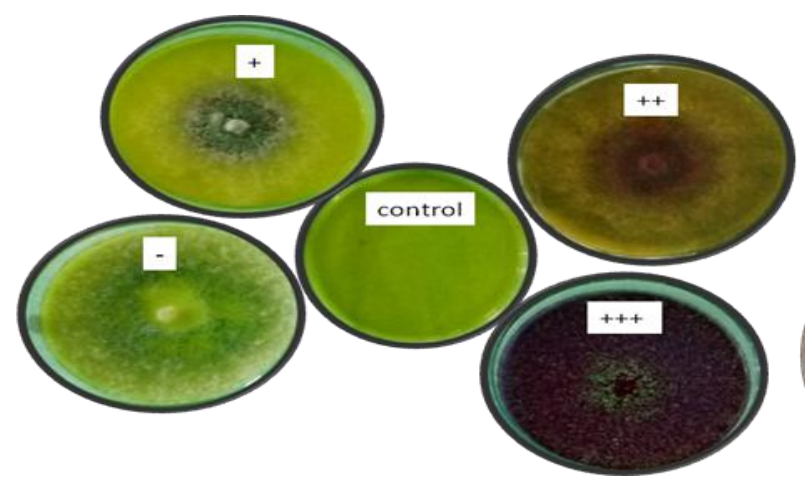

Chitinase production test

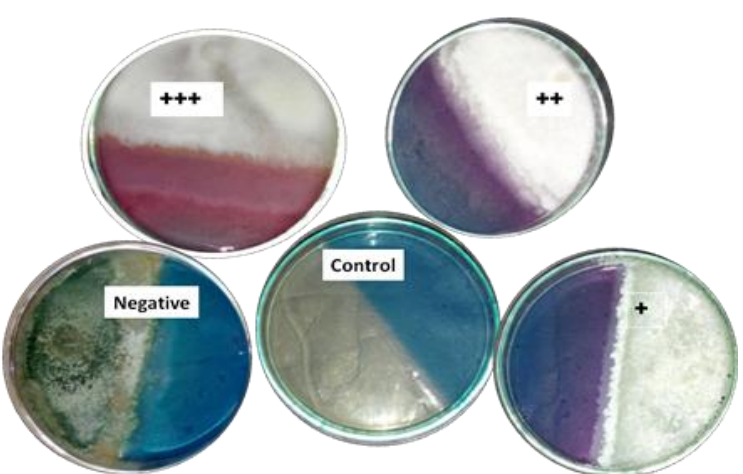

Siderophore production test
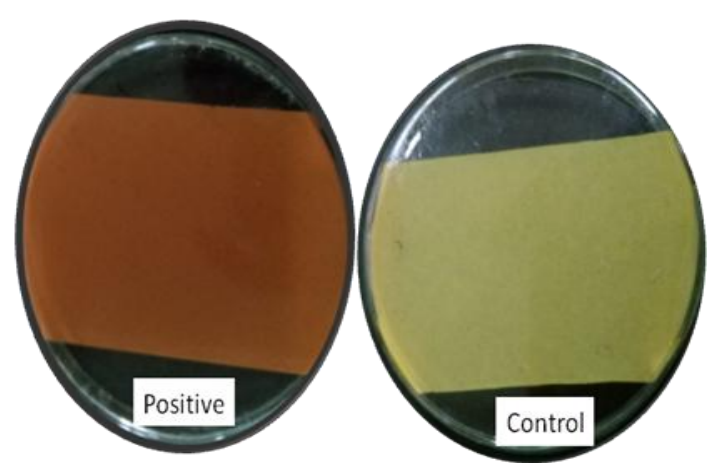

HCN production test

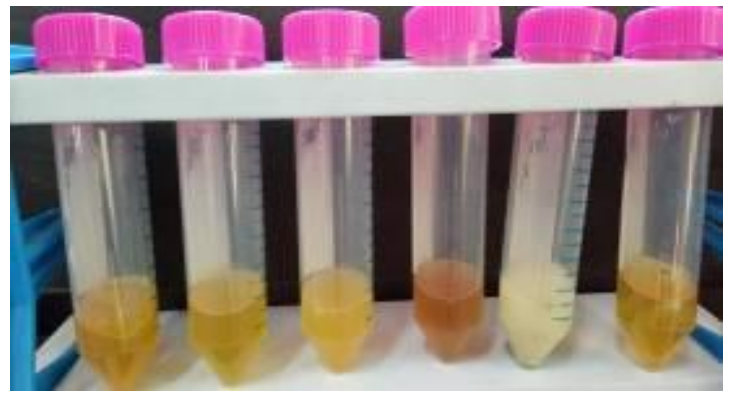

Ammonia production test

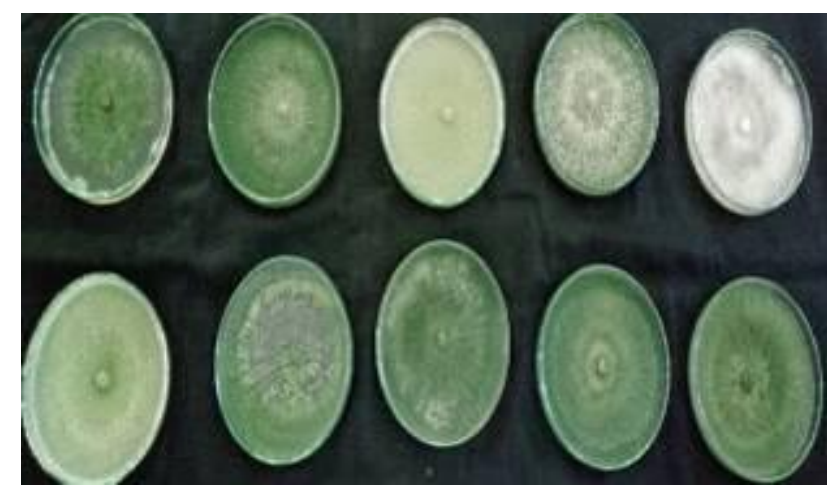

ACC deaminase production test

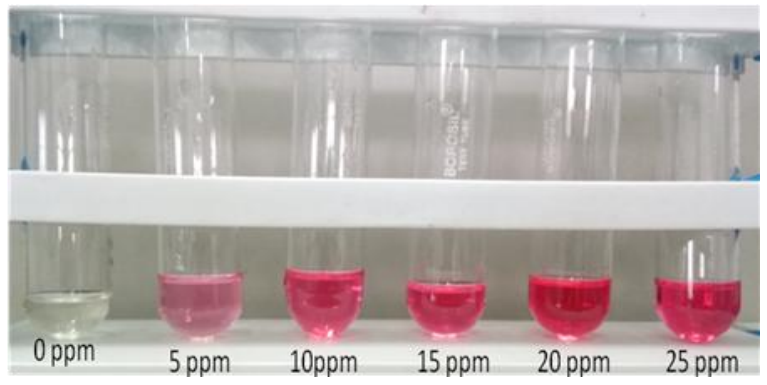

IAA production test

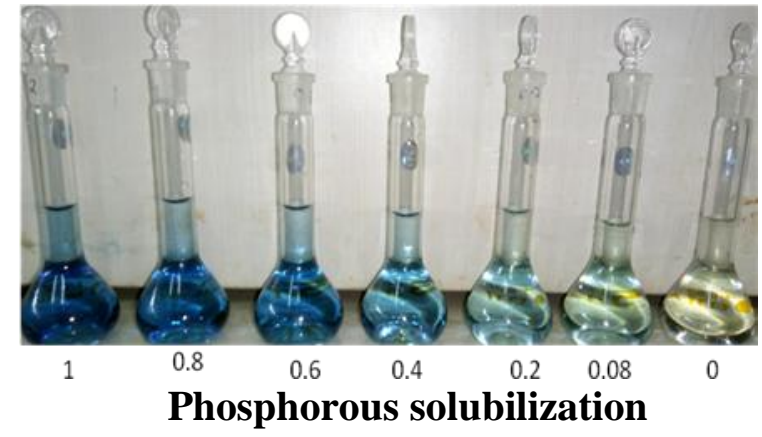


Screening for plant growth promoting traits of 20 isolates revealed that all produced IAA with TR 55 showing highest production (4.96 $\mathrm{ug} / \mathrm{ml})$ followed by others like TR 88 (4.70 $\mathrm{ug} / \mathrm{ml})$, TR $40(3.22 \mathrm{ug} / \mathrm{ml})$ and least in TR $116(0.33 \mathrm{ug} / \mathrm{ml})$. Also all produced phosphorous with highest production in TR $106(0.98 \mu \mathrm{g} / \mathrm{ml})$ followed by TR $66(0.75$ $\mathrm{ug} / \mathrm{ml})$, TR $55(0.72 \mathrm{ug} / \mathrm{ml})$ and the least was observed in TR $82(0.03 \mathrm{ug} / \mathrm{ml})$.

From 180 soil samples collected from all 11 districts of Meghalaya, 97 Trichoderma isolates were obtained which showed that Trichoderma isolates are predominant in different habitat i.e., crop rhizosphere, compost manure, sacred forest, coal mine and lime stone. The predomination of Trichoderma in natural soils, decaying wood, plant materials, crop rhizosphere were reported by several workers (Kredics et al., 2012; Kumar et al., 2012; Rai et al., 2016; Jaisani and Pandey, 2017).

Out of 97 isolates screened by dual culture against Pythium spp. and $R$. solani Kuhn., only 20 isolates colonized more than half of the growth of pathogen i.e. 50\% overgrowth. TR 55 isolated from tomato rhizosphere was found to be the most effective isolate against both Pythium spp. and $R$. solani Kuhn, showing an inhibition percentage of $89.26 \%$ and $87.41 \%$ respectively, followed by other isolates like TR 66, TR 122 and TR 136. The antagonism of Trichoderma spp. against Pythium spp. and $R$. solani were widely reported (Goud et al., 2015; Kotasthane 2015; Waghunde et al., 2016; Kumari et al., 2016; Naik et al., 2017; Rajendraprasad et al., 2017) which supported the antagonism of Trichoderma spp. against Pythium spp. and $R$. solani Kuhn. during the present investigation.

All 20 isolates screened for their PGPR and biocontrol potential such as $\mathrm{HCN}$, ammonia, siderophore, IAA, chitinase, ACC deaminase production and phosphate solubilisation showed that all 20 screened isolates were found positive for ACC deaminase production and 17 positive for chitinase production. Out of 20 screened isolates tested for other functional attributes (determining antagonistic potentials), 16 isolates were found positive for siderophore and ammonia production, whereas 13 isolates were positive for $\mathrm{HCN}$ production. Screening for plant growth promoting traits of 20 isolates revealed that all produced IAA and Phosphorous with values ranging from 0.33 to $4.96 \mu \mathrm{g} / \mathrm{ml}$ and 0.03 to $0.98 \mu \mathrm{g} / \mathrm{ml}$ respectively. The production of lytic enzymes by Trichoderma species is known as one of the major mechanisms for biocontrol activity against phytopathogenic fungi, involvement of chitinase in control of phytopathogens was reported (Harman et al., 2004a; Harighi et al., 2007, Azad et al., 2015, Thakar and Saraf 2015). HCN, siderophores and ammonia are produced by many Trichoderma spp. and are believed to play a role in biological control of pathogens (Rawat and Tiwari, 2011; Qi and Zhao, 2013, Zhang et al., 2016). Phosphate solubilizing efficiency of different isolates of Trichoderma was observed by many workers like Tallapragada and Gudimi (2011); Sarawanakumar et al., (2013); Promwee et al., (2014): Borges Chagas et al., (2015), Franca et al., (2017). ACC deaminase production of Trichoderma spp was reported by several workers (Viterbo et al., 2010; Hermosa et al., 2012; Aban et al., 2017). Aban and his co-workers also reported IAA production and phosphate solubilisation by Trichoderma yunnanense and Trichoderma simmonsil which is similar to the present findings.

In conclusion, many Trichoderma isolates were obtained from the crop rhizospheric soils in the 11 districts of Meghalaya, India. Via screening test, 20 isolates showed the best antagonism against damping off pathogens 
(Pythium spp. and R. solani) of tomato seedlings. Screening of 20 isolates for their PGPR and biocontrol potential found that almost all revealed their ability of $\mathrm{HCN}$, ammonia, siderophore, IAA, chitinase, ACC deaminase production and phosphate solubilisation. However, out of the 20 isolates, 4 Trichoderma isolates viz. TR 55, TR 66, TR 122 and TR 136 were found to be the most effective, so these 4 potent isolates need further evaluation in field condition to develop effective bio-formulation against damping off of tomato.

\section{References}

Aban, J. L., Barcelo, R. C., Oda, E. E., Reyes, G. A., Balangcod, T. D., Gutierrez, R. M, and Hipol, R. M. 2017. Auxin Production, Phosphate Solubilisation and ACC Deaminase Activity of Root Symbiotic Fungi (RSF) from Drynaria quercifolia L. Bull. Env. Pharmacol. Life Sci. 6(5): 18-23.

Abbas, A., D. Jiang, and Fu, Y. 2017. Trichoderma spp. as Antagonist of Rhizoctonia solani. J. Plant Pathol. Microbiol. 8:402. doi:10.4172/21577471.1000402 .

Anonymous, 2014. http:// www. indiastat. com/ agriculture/ 2/ vegetable/ 17427/ stat. Aspx.

Anonymous, 2018. Monthly Report Tomato. Horticulture Statistics Division Department of Agriculture, Cooperation and Farmers Welfare, Ministry of agriculture and Farmers Welfare, New Delhi.

Asad, S. A., A. Tabassum, A, Hameed, F. Hassan, A. Afzal, S.A. Khan, R. Ahmed and Shahzad, M. 2015. Determination of lytic enzyme activities of indigenous Trichoderma isolates from Pakistan. Brazilian Journal of Microbiology. 46(4): 10531064.
Asad, S.A., N. Ali, A. Hameed, S.A. Khan, R. Ahmad, M. Bilal, M. Shahzad, and Tabassum, A. 2014. Biocontrol efficacy of different isolates of Trichoderma against soil borne pathogen Rhizoctonia solani. Pol J Microbiol. 63(1): 95-103.

Bell, D.K., H.D. Wells, and Markham, C.R. 1982. In-vitro antagonism of Trichoderma spp. against six fungal plant pathogens. Phytopathol. 72:379382.

Bissett, J. 1992. Trichoderma atroviride. Canadian J. Botany. 70 (3): 639-641, 10.1139/b92-082.

Borges, C. L. F., J. A. F. Chagas, C. M. Rodrigues, L. D. Miller, and Orozco, C. B. S. 2015. Evaluation of the phosphate solubilization potential of Trichoderma strains (Trichoplus JCO) and effects on rice biomass. Journal of Soil Science and Plant Nutrition. 15 (3): 794-804.

Dhingra, O.P., and Sinclair, J.B. (1995). Basic plant pathology methods, 2nd edn. CRC press, Bocca Raton, America.

Dixit, R., R. B. Singh, and Singh, H.B. 2015. Screening of antagonistic potential and plant growth promotion activities of Trichoderma spp. and fluorescent Pseudomonas spp. isolates against Sclerotinia sclerotiorum causing stem rot of French bean. Legume Research. 38 (3): 375-381.

Franca, V. C. D., C.K. Kupper, M. RosaMagri, T. Gomes, and Rossi, F. 2017. Trichoderma spp. Isolates with potential of phosphate solubilization and growth promotion in cherry tomato. Pesquisa Agropecuaria Tropical. 47: 360-368. 10.1590/1983$40632017 \mathrm{v} 4746447$.

Gaigole, A.H., 2011. Trichoderma viride are having ability to inhibit soil borne pathogen of different crops like Rhizoctonia solani and most 
commonly used fungal bio control agent and have long been known as effective antagonist against plant pathogen. Asiatic J. Biotechnol. Resources. 2: 461-465.

Ghinaiya, H.K., and Pandya, J.R. 2017. Association and occurrence of seedborne fungal pathogens (SFP) in tomato (Solanum lycopersicum L.) Asian J. of Appl. Sci and Technol. 5(1): 06-07.

Goud, T. S., R. A. Raju, S. Karri, and Kumar, Y.S. 2015. Production and antagonistic effect of Trichoderma spp. on pathogenic microorganisms (Botrytis cinerea, Fusarium oxysporium, Macrophomina phasealina and Rhizoctonia solani). African J. Biotechnol. 14: 668-675. 10.5897/AJB2014.13904.

Gravel, V., H. Antoun, and Tweddell, R.J. 2007. Growth stimulation and fruit yield improvement of greenhouse tomato plants by inoculation with Pseudomonas putida or Trichoderma atroviride: possible role of indole acetic acid (IAA). Soil. Biol. and Biochem. 39: 1968-1977.

Harighi M.J., M.R. Zamani., Motallebi, M. 2007. Evaluation of antifungal activity of purified chitinase 42 from Trichoderma atroviride PTCC5220. Biotechnol 6:28-33.

Harman, G.E., C.R. Howell, A. Viterbo, I. Chet and M. Lorito. 2004a. Trichoderma species-opportunistic, avirulent plant symbionts. Nature Rev. Microbiol., 2: 43-56.

Hermosa, R., A. Viterbo, I. Chet, and Monte, E. 2012. Plant-beneficial effects of Trichoderma and of its genes. Microbiol. 158:17-25. DOI 10.1099/mic.0.052274-0

Jaisani, P., and Pandey, R.N. 2017. Morphological and molecular characterization for identification of isolates of Trichoderma spp. from rhizospheric soils of crops in middle Gujarat. Indian Phytopath. 70(2): 238245. doi:10.24838/ip.2017.v70.i2.71652

Jasim, B., A.A. Joseph, C.J. John, J. Mathew, and Radhakrishnan, E.K. 2014. Isolation and characterization of plant growth promoting endophytic bacteria from the rhizome of Zingiber officinale. 3 Biotech. 4(2): 197-204. doi: 10.1007/s13205-013-0143-3.

Kotasthane, A., T. Agrawal, R. Kushwah, and Rahatkar, V. 2015. In-vitro antagonism of Trichoderma spp. against Sclerotium rolfsii and Rhizoctonia solani and their response towards growth of cucumber, bottle gourd and bitter gourd. European J. of Plant Pathol. 141(3): 523-543.

Kredics, L., M. Laday, P. Kormoczi1, L. Manczinger, G. Rakhely, C. Vagvolgyi, and Szekeres, A. 2012. Genetic and biochemical diversity among Trichoderma isolates in soil samples from winter wheat fields of the Great Hungarian Plain. Acta Biologica Szegediensis. 56(2):141149.

Kumar, K., N. Amaresan, S. Bhagat, K. Madhuri, and Srivastava, R.C. 2012. Isolation and Characterization of Trichoderma spp. for Antagonistic Activity Against Root Rot and Foliar Pathogens. Indian J Microbiol. 52(2): 137-144. doi: 10.1007/s12088-0110205-3.

Kumari, A., R. Kumar, S. Maurya, and Pandey, P.K. 2016. Antagonistic Potential of Different Isolates of Trichoderma against Rhizoctonia solani.

Lamichhane, J. R., C. Durr, A.A. Schwanck, M. H. Robin, J. P. Sarthou, V. Cellier, A. Messean, and Aubertot, J.N. 2017. Integrated management of damping- 
off diseases. A review. Agronomy for Sustainable Development, Springer Verlag/EDP Sciences/INRA, pp. 37 (2): 25.

Majeed, M., M.G. Hassan, M. Hassan, F.A. Mohuiddin, S. Paswal, and Farooq, S. 2017. Damping Off in Chilli and Its Biological Management-A Review. J. Curr. Microbiol. App. Sci. 7(4): 21752185.

Manganiello, G., A. Sacco, M.R. Ercolano, F. Vinale, S. Lanzuise, A. Pascale, M. Napolitano, N. Lombardi, M. Lorito, and Woo, S.L. 2018. Modulation of Tomato Response to Rhizoctonia solani by Trichoderma harzianum and Its Secondary Metabolite Harzianic Acid. Front Microbiol. 9: 1966. doi: 10.3389/fmicb.2018.01966.

Nahar, K., and Ullah, S.M. 2012. Morphological and physiological characters of tomato (Lycopersicon esculentum Mill) cultivars under water stress. Bangladesh J. Agril. Res. 37(2): 355-360.

Naik, M.K., Y.S. Amaresh, Ravikiran, D.S. Ashwathanarayan, M.G. Patil, Mahadevaswami, D. Nair, and Shruthi, P. 2017. Morphological, Molecular Characterization of Trichoderma species Isolated from Different Rhizosphere Soils and Its Anti-Pathogenic Properties. Imperial J. of Interdisciplinary Research. Vol-3, Issue-4. http://www.onlinejournal.in

Papavizas, G.C., 1985. Trichoderma and Gliocladium: biology, ecology, and potential for biocontrol. Annual Rev. of Phytopathol. 23: 23-54.

Promwee, A., M. Issarakraisila, W. Intana, C. Chamswarng, and Yenjit, P. 2014. Phosphate Solubilization and Growth Promotion of Rubber Tree (Hevea brasiliensis Muell. Arg.) by Trichoderma Strains. J. Agricul. Science. 6. 10.5539/jas.v6n9p8.
Qi, W., and Zhao, L. 2013. Study of the siderophore-producing Trichoderma asperellum Q1 on cucumber growth promotion under salt stress. J Basic Microbiol. 53(4): 355-64. doi: 10.1002/jobm.201200031.

Rai, S., P.L. Kashyap, S. Kumar, A.K. Srivastava, and Ramteke, P.W. 2016. Identification, characterization and phylogenetic analysis of antifungal Trichoderma from tomato rhizosphere. SpringerPlus, 5(1): 1939. doi:10.1186/s40064-016-3657-4.

Rajendraprasad, M., B. Vidyasagar, G.U. Devi, and Rao, S.R.K. 2017. Biological control of tomato damping off caused by Pythium debaryanum. International J. of Chemical Studies. 5(5): 447-452.

Ramanathan, G., M. Saran Sundar, and Vinodhkumar T. 2013. Evaluation of antifungal activity of metabolites from Trichoderma species against fungal phytopathogens. International $\mathrm{J}$. of Science Innovations and Discoveries, 3(5): 528-538.

Rawat, R., and Tewari, L. 2011. Effect of abiotic stress on phosphate solubilization by biocontrol fungus Trichoderma sp. Current Microbiology, 62(5), 1521-1526. http://dx.doi.org/10.1007/s00284-0119888-2

Rifai, M.A., 1969. A revision of the genus Trichoderma. Commonow. Mycol. Inst. Mycol. pp. 116-156.

Roiger, D.J., S.N. Jeffer, and Caldwell, R. W. 1991. Occurrence of Trichoderma species in apple orchard and woodland soil. Soil Biology and Biochemistry 23, 353-359.

Rudresh, D.L., M.K. Shivaprakash, and Prasad, R.D. 2005. Tricalcium phosphate solubilizing abilities of Trichoderma spp. in relation to $\mathrm{P}$ uptake and growth and yield 
parameters of chickpea (Cicer arietinum L.). Can. J. Microbiol. 51: 217-222.

Saravanakumar, K., A.V. Shanmuga, and Kandasamy, K. 2012. Effect of Trichoderma on soil phosphate solubilization and growth improvement of Avicennia marina. Aquatic Botany. 104. 10.1016/j.aquabot.2012.09.001.

Sharma, P., M. Sharma, M. Raja, and Shanmugam V. 2014. Status of Trichoderma research in India: A review. Indian Phytopath. 67 (1): 119.

Srivastava, M.P., R. Tiwari, and Sharma N. 2013. Effect of different cultural variables on siderophores produced by Trichoderma spp. International Journal of Advanced Research. 1(7): $1-6$.

Tallapragada, P., and Gudimi, M. 2011. Phosphate solubility and biocontrol activity of Trichoderma harzianum. Turkish Journal of Biology. 35. 10.3906/biy-0911-4.

Thakkar, A., and Saraf, M. 2015. Role of Volatile Metabolites from $T$. citrinoviride in Biocontrol of Phytopathogens. Int. J. Res. Chem. Environ. 5(1): 86-95.

Thakur, N., and Tripathi, A. 2015. Biological Management of Damping-Off,
Buckeye Rot and Fusarial Wilt of Tomato (cv. Solan Lalima) under Mid-Hill Conditions of Himachal Pradesh. Agricultural Sciences. 6: 535-544.

Viterbo, A., U. Landau, S. Kim, L. Chernin, and Chet, I. 2010. Characterization of ACC deaminase from the biocontrol and plant growth-promoting agent Trichoderma asperellum T203. FEMS-Microbiol. Lett. 305: 42-48

Waghunde, Rajesh, Shelake, Rahul, N. Sabalpara, and Ambalal. 2016. Trichoderma: A significant fungus for agriculture and environment. African J. of Agricultural Research. 11: 192196. 10.5897/AJAR2015.10584.

Wardle, D.A., D. Parkinson, and Waller, J.E. 1993. Interspecific competitive interaction between pairs of fungal species in natural substrates. Ecologia 94, 165-172.

Zhang, S., Y. Gan, and Xu, B. 2016. Application of Plant-GrowthPromoting Fungi Trichoderma longibrachiatum T6 Enhances Tolerance of Wheat to Salt Stress through Improvement of Antioxidative Defense System and Gene Expression. Frontiers in plant science, 7, 1405. doi:10.3389/fpls.2016.01405.

\section{How to cite this article:}

Markidahun Biam, Dipali Majumder and Heipormi Papang. 2019. In vitro Efficacy of Native Trichoderma Isolates against Pythium spp. and Rhizoctonia solani (Kuhn.) causing Dampingoff Disease in Tomato (Solanum lycopersicum Miller). Int.J.Curr.Microbiol.App.Sci. 8(02): 566-579. doi: https://doi.org/10.20546/ijcmas.2019.802.064 